\title{
IMPACT OF TOURISM ON JAMMU \& KASHMIR ECONOMY
}

\author{
Junaid Iqbal ${ }^{1} \bigotimes$ \\ ${ }^{1}$ (Research Scholar), Department of Management and Commerce, MPhill student in RIMI University Punjab, India
}

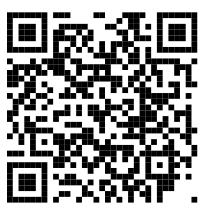

(Reariab, India

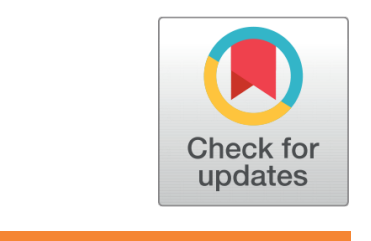

\section{ABSTRACT}

Tourism across the world is playing a great role in building the economies. Tourism is widely used for building the economic development and economic prosperity around the globe. Tourism sector is growing day by day and helping nations to build the economic prosperity of the country. Nations around the world are investing lot of money in building great infrastructure for tourism, so that they can attract tourists from around the world. Jammu \& Kashmir is one of the leading tourist destinations where tourists love to be. It is well known that around $50 \%-60 \%$ people of the state are directly or indirectly related with the tourism. Jammu and Kashmir economy is a service economy where majority of revenue is coming from tourism sector. In this paper the topic of discussion was to know the impact of tourism on Jammu and Kashmir economy. Apart from that simple regression is used to know the impact of tourism on j\&k economy while taking the factors like GDP, EMPLOYMENT and PER-CAPITA INCOME. The

Received 2 July 2021

Accepted 26 July 2021

Published 31 July 2021

Corresponding Author

Junaid Iqbal, thoker.junaid121@g

mail.com

DOI 10.29121/

granthaalayah.v9.i7.2021.4059

Funding: This research received no specific grant from any funding agency in the public, commercial, or not-for-profit sectors.

Copyright: (C) 2021 The Author(s). This is an open access article distributed under the terms of the Creative Commons Attribution License, which permits unrestricted use, distribution, and reproduction in any medium, provided the original author and source are credited.

OPEN ACCESS results of the analysis were very tremendous it shows that tourism has significant impact on the factors which has been taken as a part of paper.

There is a need to build more facilities and to work on some flaws. Tourists around the world love to visit the state because the state is blessed with the beauty of nature. The state should focus towards the infrastructure development so that more and more tourists visit every year.

Keywords: Jammu \& Kashmir, Economic Development, Infrastructure, Employment, Per-Capita Income, GDP

\section{INTRODUCTION}

The Tourism Sector is one of the fastest growing and most important economic centres in many countries around the world. The critical rate of growth and development, the amount of foreign exchange, infrastructure development, new management strategies and training experience affect different sectors of the economy, contributing positively to national and social development. The tourism industry generates a wide range of economic benefits in the host countries and in the exporting 
countries. In developing countries, one of the main reasons for supporting and promoting tourism is the expected economic growth. Therefore, tourists spend a significant amount of money buying products in the tourist area, starting with accommodation, food and beverages, leisure activities and so on, which creates a direct business and economic impact measured by income and taxes. At the same time, tourism businesses must purchase the goods and services needed to meet the needs of tourists, and direct revenue is used to further invest and purchase other goods and services. These costs incurred by tourism businesses due to the growing number of tourists have had indirect effects by creating employment opportunities and payments to other local businesses that provide goods and services to tourism businesses. Tourism is one of the largest economic sectors in the world; Travel \& Tourism creates jobs, facilitates exports, and promotes global economic prospertity. Tourism has emerged as an important sector of the global economy and has become a major factor in global trade. There has been a dramatic and significant change in the global economic situation. The importance of tourism, as a tool for economic growth and job creation, especially in remote and backyards, has been well-known around the world. The multiplicity of structures in this industry makes it the basis for economic development and facilitates balanced regional development. It is a large industry of workers with a recurring income in the economy and offers the opportunity to earn foreign exchange at low social costs. Global distribution of development programs has raised the need for exchanges between developed and developing countries. Many industrial and non-manufacturing industries, traditional and non-traditional industries, no doubt, have helped them in their major industrial transformation work but at the same time, harmful effects have caused atmospheric pollution. In addition, inadequate financial resources have also been an important obstacle to accelerating the process of economic transformation $T$ and A (2017). The northern state of Indian Jammu and kashmir shares its borders with Himachel Pradesh and Punjab and the neighbouring countries of Pakistan, China and Afganistan. The state is the combination of three regions Jammu, Kashmir and Ladakh. The state is blessed with the natural and scenic beauty which made the state a favourite destination for tourists across the world. The region of jammu is known for temples, the kashmir is famous for gardens, lakes and plains and the region of ladakh is known for mountains Paul (2018). According to the Indian Ministry of Tourism, Jammu and Kashmir Tourism Survey (1996), "Tourism is one of the most important branches of the industry." It has played an important role in the development of the economy, in particular, in the Valley region and Ladakh. The industry has provided jobs to a very large number, especially for the younger generation to generation, and the generations of economic activity in the primary, the secondary, and the secondary sectors of the state, which owes much to the industry. "The state of Jammu and Kashmir possesses the great potential to become the major tourist destination in the world. Tourism plays an important role in economic development of Jammu and Kashmir State and is an area of great interest for policy makers. Jammu and kashmir has been identified 
as an industry with the potential of development in the area of tourism. kashmir is known as the paradise on earth and is acclaimed as internationally tourist destination. Jammu region is land of temples and is attracting a large number of pilgrims every year. Ladakh region is favourite among foreign tourists and is famous for adventure tourism Nengroo et al. (2016). During the last six decades, tourism has seen increasing expansion and diversification and is becoming one of the largest and fastest-growing economic sectors in the world. The estimates made by World Travel and Tourism Council, the Travel \& Tourism's total contribution to the global economy in 2014 was US $\$ 7.6$ trillion, which equals to $9.8 \%$ of total economic GDP in 2014. In year 2014, 2.1 million new jobs were generated directly in the sector, and in total 6.1 million new jobs were created as a result of total direct, indirect and induced activity. The total contribution of Travel \& Tourism to employment grew 2.3\% in 2014, while the total GDP contribution grew 3.6\%, faster than wider economy in 2014 and registering positive growth for the 5 th successive year. In total, Travel \& Tourism supported 277 million jobs in 2014, 1 in 11 of the world's total Paul (2018). This is again evidence that Travel \& Tourism is a key engine for continued global growth and job creation. As per the estimates of United Nations World Tourism Organisation (UNWTO), global tourism receipts hit a record by earning US \$1159 billion in 2013. Despite intermittent shocks, international tourist arrivals have shown virtually continual growth from 25 million in 1950 to 278 million in 1980,528 million in 1995, and 1087 million in 2013 and are expected to reach 1.8 billion by 2030. (WTO, Tourism Highlights 2014 Edition, UNTO Publications, 2014).

\section{OBJECTIVES OF THE STUDY}

- To study and understand the impact of tourism in the economic development of J\&K.

- To study and understand the role of tourism in employment and income generation.

- To study the impact of tourism on per-capita income of Jammu \& Kashmir.

\section{RESEARCH METHODOLOGY}

This study evaluates the impact of tourism on Jammu and Kashmir economy. Simple regression method is used for conducting the study. The study is mainly based upon the collection of secondary data. Study has been conducted for the period between 2013-2018.Number of factors like gdp, employment, per-capita income and number of tourists visit during the period is used for knowing the impact of the tourism on Jammu and Kashmir economy. Simple regression has been used for estimating the impact of later on former. 


\subsection{SOURCES OF SECONDARY DATA}

Data was collected from various sources of publications such as:

- Magazines.

- Journals.

- Research articles.

- Internet.

- Newspaper (greater Kashmir).

- Published and unpublished sources of Ministry of Tourism Government of India and J\&K tourism.

\subsection{SIMPLE REGRESSION MODEL EQUATIONS}

- Employment $\mathrm{Yi}=\alpha+\operatorname{tourism} \beta \mathrm{i}+\varepsilon$ (1)

- Gross Domestic productY2= $\alpha+\operatorname{tourism} \beta 2+\varepsilon$ (2)

- Per-capita Income Y3 $=\alpha+\operatorname{tourism} \beta 3+\varepsilon$ (3)

\subsection{NULL HYPOTHESIS}

- There is no significant impact of tourism on employment of j\&k economy.

- There is no significant impact of tourism on gdp of j\&k economy.

- There is no significant impact of tourism on per-capita income of j\&k economy.

\section{DATA COLLECTION AND ANALYSIS:}

Table 1 Table on impact of tourism on j\&k economy between 2013-2018

\begin{tabular}{ccccc}
\hline Year & No of tourists lakhs & Employment lakhs & GDP & Per capita income \\
\hline $2013-2014$ & 109.05 & 20.754 & 6.39 & 61108 \\
\hline $2014-2015$ & 147.34 & 22.101 & 7.51 & 61185 \\
\hline $2015-2016$ & 158.29 & 23.7435 & 8.01 & 73054 \\
\hline $2016-2017$ & 170.09 & 25.5135 & 7.11 & 77918 \\
\hline $2017-2018$ & 182.78 & 27.417 & 11.71 & 86108 \\
\hline
\end{tabular}

Source: Santek Consultants Pvt. Ltd. New Delhi.

\subsection{DATA ANALYSIS}

FIRST NULL HYPOTHESIS

- There is no significant impact of tourism on employment of j\&k economy 


\begin{tabular}{lccc}
\hline Table 2 & \multicolumn{3}{l}{ Descriptive Statistics } \\
\hline & Mean & Std. Deviation & N \\
\hline Employment & 23.91 & 2.652 & 5 \\
\hline No of tourist & 153.51 & 28.148 & 5 \\
\hline
\end{tabular}

\section{INTERPRETATION}

This model tells us that the mean of the data is 23.91 while calculating on employment in last 5 years while mean 153.51 shows that the tourists inflow has significant impact on the employment generation of the j\&k. Standard deviation results on both employment 2.62 and inflow of tourist 28.148 shows that with the increase in the flow of tourists there is a great scope of further employment opportunities in near future. Tourism has a great future in the state and it can immensely affect the employment generation of the state.

Table 3 Correlations

\begin{tabular}{cccc}
\hline & & Employment & No of tourist \\
\hline \multirow{2}{*}{ Pearson Correlation } & Employment & 1.000 & .937 \\
& No of tourist & .937 & 1.000 \\
& Employment &. & .009 \\
\hline & No of tourist & .009 &. \\
\hline & Employment & 5 & 5 \\
\hline
\end{tabular}

\section{INTERPRETATION}

Co-efficient of correlation has been used to find the relationship between the number of tourists and employment while taking the data of five years. As the values of both no of tourists (0.937) and employment (1.00) shows that there is highest degree of correlation between the variables. Number of tourist's works as independent variable and employment is taken as dependent variable. The analysis shows there is highest correlation between number of tourists and employment as the figures suggest. With the increase in the number of tourists there will be the scope further employment generation opportunities.

One tale test is used to know whether the analysis is significant or not. As the values show that both number of tourist and employment is going in the same direction (.009) that means that analysis is significant and relevant. It shows that both the estimated value and reference value is going in the same direction. It depicts that if one will go in negative direction other will follow it and vice versa.

\section{INTERPRETATION}




\begin{tabular}{cccccc}
\hline \multicolumn{2}{l}{ Table 4} & Model summary & & \\
\hline Model & $\mathbf{R}$ & $\begin{array}{c}\mathbf{R} \\
\text { Square }\end{array}$ & $\begin{array}{c}\text { Adjusted } \mathbf{R} \\
\text { Square }\end{array}$ & $\begin{array}{c}\text { Std. Error of the } \\
\text { Estimate }\end{array}$ & $\begin{array}{c}\text { Durbin- } \\
\text { Watson }\end{array}$ \\
1 & $.937^{a}$ & .879 & .838 & 1.066 & 1.684
\end{tabular}

a. Predictors: (Constant), No of tourist

b. Dependent Variable: Employment

This table provides the $\mathrm{R}$ and $\mathrm{R}^{2}$ values. The $\mathrm{R}$ value represents the simple correlation and is 0.937 (the " $\mathrm{R}$ " Column), which indicates a high degree of correlation. The $\mathrm{R}^{2}$ value (the "R Square" column) indicates how much of the total variation in the dependent variable, employment can be explained by the independent variable number of tourists. In this case $87.9 \%$ can be explained, which is very large.

As i earlier mentioned that our models depict the impact of independent variable on the dependent variable. $\mathrm{R}$ Denotes the correlation between independent variable (number of tourists) and dependent variable (employment). In this case $\mathrm{R}=0$. 937.Since this high level of correlation between the two variables. Our model shows the analysis more precisely.

$\mathrm{R}$ square is simply the square of R.R square is 0.879. It indicates the proportion of variance in employment that can be explained by our independent variable (number of tourists).

The Regression maximises the R square for our samples, it will be somewhat lower for the entire state economy, a phenomenon known as shrinkage. The Adjusted $\mathrm{R}$ square estimates the economy $\mathrm{R}$ square for our model and gave us more realistic indication of it influence.

The high adjusted R squared tells us that our model does a great job in estimating the impact of number of tourists on the employment.

Durbin-Watson determines whether there is autocorrelation in the residuals of a time series regression. The value of the Durbin-Watson is 1.684 as there is no auto correlation between the two variables.

\begin{tabular}{ccccccc}
\hline \multicolumn{2}{c}{ Table 5 ANOVA } & \multicolumn{1}{c}{} \\
\hline & Model & Sum of Squares & df & Mean Square & F & Sig. \\
1 & Regression & 24.723 & 1 & 24.723 & 21.767 & $.019^{b}$ \\
\hline & Residual & 3.408 & 3 & 1.136 & & \\
Total & 28.131 & 4 & & & \\
\hline
\end{tabular}

a. Dependent Variable: Employment

b. Predictors: (Constant), No of tourist

\section{INTREPRETATION}

This is the table that shows the output of the ANOVA analysis and whether there is a statistically significant difference between our group means. We can see that the significance value is 0.019 (i.e., $p=0.019$ ), which is below 0.05 . and therefore, there is 
a statistically significant difference in the mean length of time to complete the spread sheet problem between the dependent variable (employment) and independent variable (no of tourists) taken.

This table indicates that the regression model predicts the dependent variable significantly well. By Looking at the Regression row and go to the Sig column. This indicates the statistical significance of the regression model that was run. Here the Sig is 0.019 which is less than 0.05 , and indicates that the overall regression model statistically significantly predicts the outcome of variable (i.e., it is a good fit for the data).

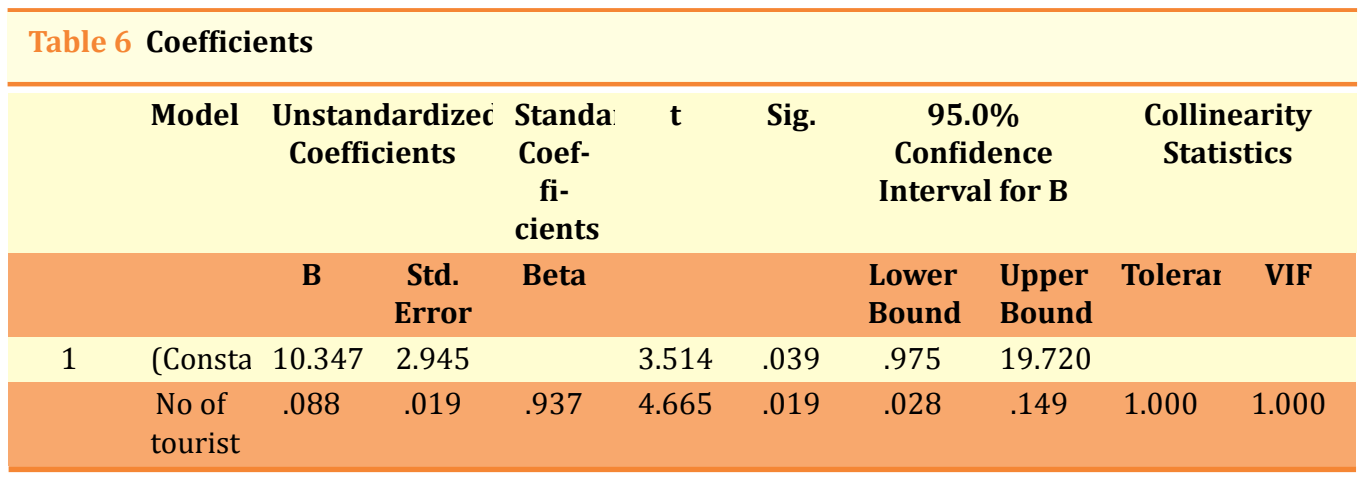

a. Dependent Variable:Employment

\section{INTREPRETATION}

The b coefficients tell us how many employment opportunities increases with the increase in number of tourists. Like so, $1 \% \mathrm{t}$ increase in the tourist inflow corresponds to $0.088 \%$ increase in the employment.

Importantly, note that all $\mathrm{b}$ coefficients are positive numbers; higher number of tourists is associated with higher employment and so on. B coefficients having the "wrong direction" often indicate a problem with the analysis known as multi collinearity.

The column Sig. holds the significance levels for our independent variable. As a rule of thumb, we say that a b coefficient is statistically significant if its p-value (Sig value) is smaller than 0.05 . All of our b coefficients are statistically significant.

P-values are:

0.039 and 0.019

Our p-value (sig values) is less than 0.05 and therefore we can say that b coefficient values are statistically correct.

The beta coefficients allow us to compare the relative strengths of our independent variable. Like if the number of tourists increases in the coming years it has the ability to create more jobs. It can help to fulfil the unemployment gaps. Tourism has the immense effect on the employment generation of the state. 


\begin{tabular}{cccccc}
\hline Table 7 Residuals Statistics & & & & \\
\hline & Minimum & Maximum & Mean & Std. Deviation & N \\
Predicted Value & 19.98 & 26.49 & 23.91 & 2.486 & 5 \\
\hline Residual & -1.260 & .926 & .000 & .923 & 5 \\
Std. Predicted Value & -1.580 & 1.040 & .000 & 1.000 & 5 \\
\hline Std. Residual & -1.182 & .869 & .000 & .866 & 5 \\
\hline
\end{tabular}

a. Dependent Variable: Employment

Residual Statistics helps us to know the difference between the observed variable (Employment) and the predicted value (number of tourists). It is worth to get a better understanding of the spread of values that the model predicts and the range of error within the model. The table shows the residuals suggests that they are close to being normally distributed but there are more residuals close to zero than perhaps you would expect. There seem to be some deviation from normality between the observed cumulative probabilities but it appears to be minor. Overall, there does not appear to be a severe problem with non-normality of residuals. Standard deviation is showing less deviation from the maximum value that means the analysis is fit for the data. In this section the table defines that if independent value increases or decreases how much it affects the other dependent value. It shows how much the value of dependent variable alter when there is a change in another variable

The motive here is to know the impact of independent variable on dependent variable like if independent variable changes $1 \%$ how much change it could bring to the dependent variable.

\section{SECOND NULL HYPOTHESIS}

- There is no significant impact of tourism on GDP of j\&k economy

\begin{tabular}{cccc}
\hline Table 8 Descriptive Statistics \\
\hline & Mean & Std. Deviation & N \\
\hline GDP & 8.15 & 2.079 & 5 \\
\hline No of tourist & 153.51 & 28.148 & 5 \\
\hline
\end{tabular}

\section{INTERPRETATION}

This model tells us that the mean of the data is 8.15 while calculating on employment in last 5 years while mean 153.51 shows that the tourists inflow has significant impact on the GDP of the j\&k. Standard deviation results on both gross domestic product (GDP) 2.079 and inflow of tourist 28.148 shows that with the increase in the flow of tourists the value of the gross domestic product has a good possibility to increase. Tourism has a great future in the state and it can immensely affect the gross domestic product (GDP) of the state. 
The possibility here is one is directly dependent on other. The positive increase in flow of tourists has a tendency to immensely impact the economy of the state. As the tourism is the backbone of the state, data in the table shows that clearly. Good facilities and adequate environment can help to bring such changes in the state.

With the increase in gross domestic product (GDP) this will help to solve the several problems of the state like poverty, infrastructure development, employment generation, environment sustainability, investment and so on.

\begin{tabular}{cccc}
\hline Table 9 Correlations & & & \\
\hline & & GDP & No of tourist \\
\hline Pearson Correlation & GDP & 1.000 & .720 \\
& No of tourist & .720 & 1.000 \\
Sig. (1-tailed) & GDP &. & .085 \\
& No of tourist & .085 &. \\
\hline N & GDP & 5 & 5 \\
& No of tourist & 5 & 5 \\
\hline
\end{tabular}

\section{INTERPRETATION}

Co-efficient of correlation has been used to find the relationship between the number of tourists and gross domestic product while taking the data of five years. As the value of both number of tourists (1.00) and gross domestic product (GDP) (0.720) shows that there is highest degree of correlation between the variables. Number of tourist's works as independent variable and gross domestic product (GDP) is taken as dependent variable. The analysis shows there is highest correlation between number of tourists and employment as the figures suggest. With the increase in the number of tourists there will be the scope further increase in gross domestic product (GDP) of the state.

Gross Domestic Product is directly dependent on inflow of tourists. The data in the table clearly demonstrates that how the flow of tourists directly impacting the gross domestic products of the state (GDP).

One tale test is used to know whether the analysis is significant or not. As the values show that both number of tourist and gross domestic product (GDP) is going in the same direction (.085) that means that analysis is significant and relevant. It shows that both the estimated value and reference value is going in the same direction. It depicts that if one will go in negative direction other will follow it and vice versa.

\begin{tabular}{llllll}
\hline Table 10 & Model Summary & & \\
\hline Model & $\mathbf{R}$ & R Square & Adjusted R Square & Std. Error of the Estimate & Durbin-Watson \\
1 & $.720^{a}$ & .518 & .358 & 1.666 & 2.233 \\
\hline
\end{tabular}

\footnotetext{
a. Predictors: (Constant), No of tourist
}

b. Dependent Variable: GDP 


\section{INTERPRETATION}

This table provides the $\mathrm{R}$ and $\mathrm{R}^{2}$ values. The $\mathrm{R}$ value represents the simple correlation and is 0.720 (the " $\mathrm{R}$ " Column), which indicates a high degree of correlation. The $\mathrm{R}^{2}$ value (the "R Square" column) indicates how much of the total variation in the dependent variable, gross domestic product (GDP) can be explained by the independent variable number of tourists. In this case $51.8 \%$ can be explained, which is very large. As mentioned earlier that our models depict the impact of independent variable on the dependent variable. $R$ Denotes the correlation between independent variable (number of tourists) and dependent variable (gross domestic product). In this case $\mathrm{R}=0$. 720.Since this high level of correlation between the two variables. Our model shows the analysis more precisely. $\mathrm{R}$ square is simply the square of R.R square is 0.518 . It indicates the proportion of variance in employment that can be explained by our independent variable (number of tourists). The Regression maximises the $\mathrm{R}$ square for our samples, it will be somewhat lower for the entire state economy, a phenomenon known as shrinkage. The Adjusted R square estimates the economy for our model and gave us more realistic indication of it influences. The high adjusted $\mathrm{R}$ squared tells us that our model does a great job in estimating the impact of number of tourists on the gross domestic product (GDP). Durbin-Watson determines whether there is autocorrelation in the residuals of a time series regression. The value of the Durbin-Watson is 2.233 as there is auto correlation between the two variables.

\begin{tabular}{lcccccc}
\hline \multicolumn{2}{|c}{ Table 11 ANOVA } \\
\hline \multicolumn{10}{c}{ Model } & Sum of Squares & df & Mean Square & F & Sig. \\
\hline 1 & Regression & 8.957 & 1 & 8.957 & 3.228 & $.170^{b}$ \\
\hline & Residual & 8.325 & 3 & 2.775 & & \\
Total & 17.282 & 4 & & & \\
\hline \\
a. Dependent Variable: GDP \\
b. Predictors: (Constant), No of tourist
\end{tabular}

\section{INTREPRETATION}

This is the table that shows the output of the ANOVA analysis and whether there is a statistically significant difference between our group means. We can see that the significance value is 0.170 (i.e., $p=0.170$ ), which is above 0.05 . and therefore, there is a statistically insignificant difference in the mean length of time to complete the spread sheet problem between the dependent variable (gross domestic product) and independent variable (no of tourists) taken.

This table indicates that the regression model predicts the dependent variable insignificantly well. By Looking at the Regression row and go to the Sig column. This indicates the statistical insignificance of the regression model that was run. Here the Sig is 0.170 which is greater than 0.05 , and indicates that the overall regression model is statistically insignificant to predict the outcome of variables (i.e., it is not good fit for the data). 


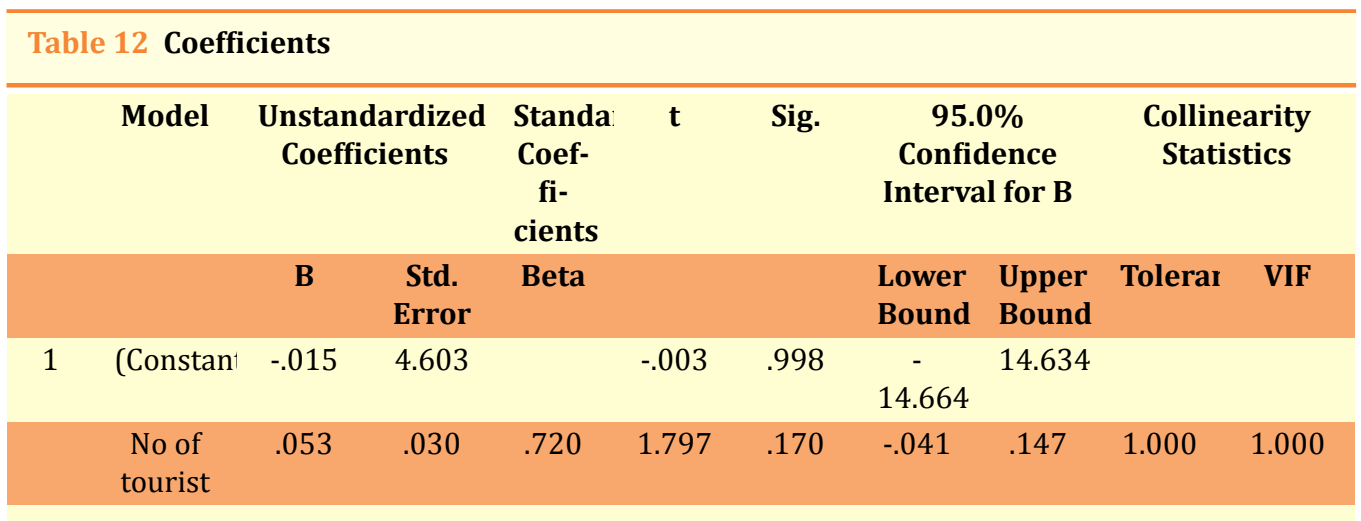

a. Dependent Variable: GDP

\section{INTERPRETATION}

The b coefficients tell us how many employment opportunities increases with the increase in number of tourists. Like so, $1 \%$ increase in the tourist inflow corresponds to $0.053 \%$ increase in the gross domestic product. Importantly, note that all b coefficients are positive numbers; higher number of tourists is associated with higher employment and so on. If the $b$ coefficient has some negative numbers, it will reduce its impact like shown in the table. B coefficients having the "wrong direction" often indicate a problem with the analysis known as multi collinearity.The column Sig. holds the significance levels for our independent variable. As a rule of thumb, we say that a b coefficient is statistically significant if its p-value (Sig value) is smaller than 0.05 . All of our $b$ coefficients are statistically significant.

P-values are:

\subsection{8 and 0.170}

Our p-value (sig values) is greater than 0.05 and therefore we can say that b coefficient values are statistically insignificant. It depicts that with the decrease in the number of tourists it could directly affect the gross domestic product (GDP) of the state.

\begin{tabular}{cccccc}
\hline Table 13 Residuals Statistics & & & & \\
\hline & Minimum & Maximum & Mean & Std. Deviation & N \\
Predicted Value & 5.78 & 9.70 & 8.15 & 1.496 & 5 \\
Residual & -1.917 & 2.008 & .000 & 1.443 & 5 \\
Std. Predicted Value & -1.580 & 1.040 & .000 & 1.000 & 5 \\
Std. Residual & -1.151 & 1.205 & .000 & .866 & 5 \\
\hline
\end{tabular}

a. Dependent Variable: GDP

\section{INTREPRETATION}

Residual Statistics helps us to know the difference between the observed variable (GDP) and the predicted value (number of tourists). It is worth to get a bet- 
ter understanding of the spread of values that the model predicts and the range of error within the model. The table shows the residuals suggests that they are close to being normally distributed but there are more residuals close to zero than perhaps you would expect. There seem to be some deviation from normality between the observed cumulative probabilities but it appears to be minor. Overall, there does not appear to be a severe problem with non-normality of residuals. Standard deviation is showing less deviation from the maximum value that means the analysis is fit for the data.

In this section the table defines that if independent value increases or decreases how much it affects the other dependent value. It shows how much the value of dependent variable alters when there is a change in another variable. The motive here is to know the impact of independent variable on dependent variable like if independent variable changes $1 \%$ how much change it could bring to the dependent variable.

\section{THIRD NULL HYPOTHESIS}

3. There is no significant impact of tourism on employment of $j \& k$ economy

Table 14 Descriptive Statistics

\begin{tabular}{cccc}
\hline & Mean & Std. Deviation & N \\
LG Per-capita & 4.8526 & .06560 & 5 \\
\hline No of tourist & 153.51 & 28.148 & 5 \\
\hline
\end{tabular}

\section{INTREPRETATION}

This model tells us that the mean of the data is 4.8526 while calculating on employment in last 5 years while mean 153.51 shows that the tourists inflow has significant impact on the GDP of the j\&k. Standard deviation results on both Per Capita income 0.06560 and inflow of tourist 28.148 shows that with the increase in the flow of tourists the value of the per-capita income has a good possibility to increase. Tourism has a great future in the state and it can immensely affect the earnings of the people of the state.

The possibility here is one is directly dependent on other. The positive increase in flow of tourists has a tendency to immensely impact the economy of the state. As the tourism is the backbone of the state as data in the table shows that clearly.

Good facilities and adequate environment can help to bring such changes in the states per-capita -income which could lead to the good standard of living.

With the increase in per-capita income this will help to solve the several problems of the state like poverty, infrastructure development, employment generation, standard of living and so on. 


\begin{tabular}{cccc}
\hline \multicolumn{2}{l}{ Table 15 Correlations } & & \\
\hline & & LG Per-capita & No of tourist \\
\hline Pearson Correlation & LG Per-capita & 1.000 & .877 \\
& No of tourist & .877 & 1.000 \\
Sig. (1-tailed) & LG Per-capita &. & .025 \\
& No of tourist & .025 &. \\
\hline & LG Per-capita & 5 & 5 \\
& No of tourist & 5 & 5 \\
\hline
\end{tabular}

\section{INTERPRETATION}

Co-efficient of correlation has been used to find the relationship between the number of tourists and gross domestic product while taking the data of five years. As the value of both number of tourists (1.00) and Per-Capita Income (0.877) shows that there is highest degree of correlation between the variables. Number of tourist's works as independent variable and Per-Capita Income is taken as dependent variable. The analysis shows there is highest correlation between number of tourists and Per-Capita Income as the figures suggest. With the increase in the number of tourists there will be the scope for further increase in Per-capita Income of the state.

Per-Capita Income is directly dependent on inflow of tourists. The data in the table clearly demonstrates that how the flow of tourists directly impacting the Per-capita Income of the state.

The increase in Per-Capita Income would increase the purchasing power of the people living in the state. Increase in Per-capita Income here means that it will improve the living habits of the people of the state.

One tale test is used to know whether the analysis is significant or not. As the values show that both number of tourist and Per-Capita Income is going in the same direction (.025) that means that analysis is significant and relevant. It shows that both the estimated value and reference value is going in the same direction. It depicts that if one will go in negative direction other will follow it and vice versa.

Table 16 Model Summary

\begin{tabular}{cccccc}
\hline Model & R & R Square & $\begin{array}{c}\text { Adjusted } \\
\text { R Square }\end{array}$ & Std. Error of the Estimate & $\begin{array}{c}\text { Durbin- } \\
\text { Watson }\end{array}$ \\
\hline 1 & $.877^{a}$ & .769 & .692 & .03642 & 2.348 \\
\hline
\end{tabular}

a. Predictors: (Constant), No of tourist

b. Dependent Variable: LG Per-capita income

\section{INTERPRETATION}

This table provides the $\mathrm{R}$ and $\mathrm{R}^{2}$ values. The $\mathrm{R}$ value represents the simple correlation and is 0.877 (the " $\mathrm{R}$ " Column), which indicates a high degree of correlation. The $\mathrm{R}^{2}$ value (the "R Square" column) indicates how much of the total variation in the dependent variable, Per-Capita Income can be explained by the independent vari- 
able number of tourists. In this case $76.9 \%$ can be explained, which is very large. As i earlier mentioned that our models depict the impact of independent variable on the dependent variable. R Denotes the correlation between independent variable (number of tourists) and dependent variable (Per-Capita Income). In this case $\mathrm{R}=0$. 877.Since this high level of correlation between the two variables. Our model shows the analysis more precisely. R square is simply the square of R.R square is 0.7698 . It indicates the proportion of variance in Per-Capita Income that can be explained by our independent variable (number of tourists).

The Regression maximises the R square (0.692) for our samples, it will be somewhat lower for the entire state economy, a phenomenon known as shrinkage. The Adjusted R square estimates the economy for our model and gave us more realistic indication of its influence.

The high adjusted $\mathrm{R}$ squared tells us that our model does a great job in estimating the impact of number of tourists on the Per-Capita Income. Durbin-Watson determines whether there is autocorrelation in the residuals of a time series regression. The value of the Durbin-Watson is 2.348 as there is auto correlation between the two variables.

\begin{tabular}{ccccccc}
\hline \multicolumn{2}{c}{ Table 17 ANOVA } & \multicolumn{1}{c}{} \\
\hline \multicolumn{1}{c}{ Model } & Sum of Squares & df & Mean Square & F & Sig. \\
\hline & Regression & .013 & 1 & .013 & 9.979 & $.051^{b}$ \\
\hline & Residual & .004 & 3 & .001 & & \\
\hline & Total & .017 & 4 & & & \\
\hline
\end{tabular}

a. Dependent Variable: LG Per-capita income

b. Predictors: (Constant), No of tourist

\section{INTREPRETATION}

This is the table that shows the output of the ANOVA analysis and whether there is a statistically significant difference between our group means. We can see that the significance value is 0.051 (i.e., $p=0.051$ ), which is equal to 0.05 . and therefore, there is a statistically significant difference in the mean length of time to complete the spread sheet problem between the dependent variable (Per-Capita Income) and independent variable (no of tourists) taken. This table indicates that the regression model predicts the dependent variable significantly well. By Looking at the Regression row and go to the Sig column. This indicates the statistical significance of the regression model that was run. Here the Sig is 0.051 which is equal to 0.05 , and indicates that the overall regression model is statistically significant to predict the outcome of variable (i.e., it is not good fit for the data). 


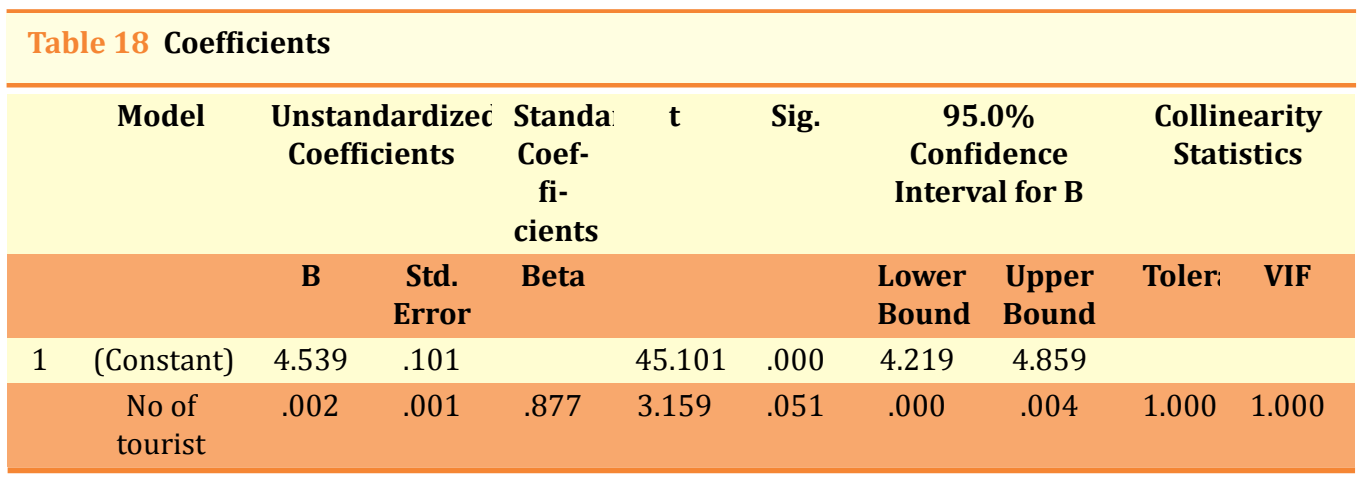

a. Dependent Variable: LG Per-capita income

\section{INTERPRETATION}

The $b$ coefficients tell us how much Per-capita income increases with the increase in number of tourists. Like so, $1 \%$ increase in the tourist inflow corresponds to $0.02 \%$ increase in the gross domestic product. Importantly, note that all b coefficients are positive numbers; higher number of tourists is associated with the higher Per-Capita Income and so on. If the $b$ coefficient has some negative numbers, it will reduce its impact like shown in the table. B coefficients having the "wrong direction" often indicate a problem with the analysis known as multi collinearity.The column Sig. holds the significance levels for our independent variable. As a rule of thumb, we say that a b coefficient is statistically significant if its p-value (Sig value) is smaller than 0.05 . All of our b coefficients are statistically significant.

\section{P-values are:}

\subsection{0 and 0.051}

Our p-value (sig values) is less and equal to 0.05 and therefore we can say that $b$ coefficient values are statistically significant. It depicts that with the decrease in the number of tourists it could directly affect the Per-Capita Income of the state. The beta coefficients allow us to compare the relative strengths of our independent variable. Like if the numbers of tourists increase in the coming years so, it will be beneficial for the state and helps to create more jobs. It can help to fulfil the unemployment gaps. Tourism has the immense ability to increase the economic prosperity of the state. Increasing number of Tourists will increase the Per-capita Income of the state and also increase the economic development of the state

\begin{tabular}{cccccc}
\hline \multicolumn{7}{l}{ Table 19 Residuals Statistics } & & & & \\
\hline & Minimum & Maximum & Mean & Std. Deviation & N \\
Predicted Value & 4.7618 & 4.9124 & 4.8526 & .05752 & 5 \\
Residual & -.05336 & .02434 & .00000 & .03154 & 5 \\
Std. Predicted Value & -1.580 & 1.040 & .000 & 1.000 & 5 \\
Std. Residual & -1.465 & .668 & .000 & .866 & 5 \\
\hline
\end{tabular}

a. Dependent Variable: LG Per-capita income 


\section{INTERPRETATION}

Residual Statistics helps us to know the difference between the observed variable (GDP) and the predicted value (number of tourists). It is worth to get a better understanding of the spread of values that the model predicts and the range of error within the model. The table shows the residuals suggests that they are close to being normally distributed but there are more residuals close to zero than perhaps you would expect. There seem to be some deviation from normality between the observed cumulative probabilities but it appears to be minor. Overall, there does not appear to be a severe problem with non-normality of residuals. Standard deviation is showing less deviation from the maximum value that means the analysis is fit for the data. In this section the table defines that if independent value increases or decreases how much it affects the other dependent value. It shows how much the value of dependent variable alter when there is a change in another variable. The motive here is to know the impact of independent variable on dependent variable like if independent variable changes $1 \%$ how much change it could bring to the dependent variable.

\section{SCOPE OF THE STUDY}

The study includes the impact of tourism on Jammu and Kashmir economy. This study is restricted to Jammu and Kashmir only. The study is only applicable to Jammu and Kashmir only. The data used for the study is secondary and is taken between the years 2013-2018.To know the impact of tourism on the state economy number of variables have been included in the study like gross domestic product (GDP), PerCapita Income and employment. The study demonstrates that the tourism is one of the main pillars of j\&k economy. Tourism has the immense effect on the different aspects of the state like employment, standard of living, infrastructure development, sustainable development, Per-capita income. The study also reveals if there is a decrease in the number of tourists visit to the state it will directly impact the state economy. Because $\mathrm{j} \& \mathrm{k}$ economy is service economy and tourism is one of the vast sources of income for the state. States main source of earning is coming from the tourism itself. Tourism plays a major role around the world in boosting the economy of the countries. Countries spend large amount of money to develop the infrastructure facilities for the tourism so that the maximum number of tourists visit there. Tourism industry has an ability to increase the foreign trade and develop the good relation across the world; it also plays a good role in developing the policies of the country. There is need to develop the policies that makes it easy for the visitors to visit the state so that they will enjoy the beauty. Infrastructure development, communication facilities, proper roads, accommodation facilities and sustainable development of the environment should be developed that helps to attract the attention of more tourists. Increase in the number of tourists means the development of the state. There is a need to develop the modern techniques of marketing and advertise- 
ment to promote the tourism. Attractive and smart advertisement helps to attract the tourists towards the state.

The tourism industry has great potential for job creation and has also benefited from a large amount of foreign exchange without giving impetus to global economic growth. With the capacity and skills of the tourism industry to grow, research makes a strong case for paying proper attention to national policy in order to make a significant contribution to the J\&K economy in terms of profitability, employment and helping to improve quality of life.

\section{FINDINGS}

Jammu and Kashmir are known for the tourism across the world. The state is blessed with the scenic beauty of nature. That offers the shining streams, high mountains and verdant land that have the classic beauty which catches people from every corner of the world. The tourism sector is the main source of revenue for the government. The whole study is based on secondary data and simple regression analysis is used to find out the impact of tourism on the economy of the state. The results of the study are as under:

- There is a direct relationship between the number of tourists visit and the employment generation of the state.

- The study reveals that with the increase in the flow of tourist it increases the chances for generating the more employment opportunities for the state.

- From the analysis we found that the tourism has great influence on the gross domestic product (GDP) of the state.

- The study shows there is direct relationship between the number of tourists visit and the GDP of the state. It specifies that a greater number of tourists means increase in the GDP of the state.

- It further indicates that tourism sector has a great impact on the economic development of the state. It helps to develop the regional development and increase the economic strength of the people.

- The analysis shows that Tourism has the capability to increase the income of the people. As the income of the people is directly dependent on the tourism activities.

- The study reveals that there is positive relationship between the per-capita income and number of tourists visit during the year.

- The study shows that the tourism needs more government attention so that the favourable policies should be framed to increase the development of the state by promoting the tourism.

- The study also shows that sate has a good future in tourism but the need is to develop the more and more infrastructural facilities for the visitors. 
- In the future it can surely employ the lakhs of people and increase the economic strength of the state. The future of the tourism industry is bright in future.

\section{CONCLUSION}

The study reveals that tourism is playing the major role in the development of the Jammu and Kashmir region. Tourism development has been done significantly for the development of region over the past several decades. Perhaps state is rich in scenic beauty and other cultural attractions. The research study finds that tourism is playing a positive role in the economic development of Jammu and Kashmir. Tourism is now playing a serious role everywhere in the world as one of the major means of developing the economy of the country. Studies and researches, both academic and practical, on tourism development and its manifold impacts have now become highly significant in developed as well as under developed countries. This is seldom true in the case of Jammu and Kashmir, where industrial development is very low. The only sector in the present situation upon which Jammu and Kashmir can rely upon with full faith is the development of tourism. The main sources of revenue for the state come from the tourism sector. Indeed, Kashmir has created its brand name in tourism "Paradise on the earth".

Tourism is the backbone of Jammu and Kashmir and all possible efforts should be undertaken for retaining, maintaining and sustaining it. Tourism opens up new opportunities for resources, both investment generation and revenue generation leading to employment generation, increase in income as well as socio-economic development of the state.

It is found from analysis that Tourism is the leading industry in the J\&K economy and proves to be the life line of the state economy. J\&K state is one of the leading attractions for the domestic as well as international tourists; it has the potential to bring huge inflow of tourists who want to travel to seek pleasure from the beauty that the state possesses. The Tourism sector has greater employment capability and generates sufficient revenue which has shown great increase over the years. The revenue generation is expected to increase seldom provided the situation remains normal and the tourist arrival increases in a desired manner.

The tourism infrastructure is a need of hour that helps to attract more and more tourists like big roads, transport including Airlines and Rail services, up gradation of hotels, infrastructural development of tourist places in Jammu and Kashmir should be build up to the good level. There is a serious need to build alternative roads in some places to ensure better connectivity. Numerous steps should be taken to restore the old historic places. There is need to focus on the religious sites in all the three regions of Jammu and Kashmir for the development of basic infrastructure to attract pilgrims in bulk numbers.

To conclude there is a further need to bring the modern techniques and tools to facilitate the tourists in a different way. Tourism industry has a great future in valley 
as the analysis shows how much effect it has on the lives of the people of the state. Conducive environment and up

gradation of the various facilities which has been discussed earlier can help to catch the attention of more tourists. It plays a major role in development of the state's economic development, government needs to develop more and more liberal policies so that it helps to generate more employment and improve the standard of living of the people.

\section{REFERENCES}

Articles on Greater Kashmir regarding the tourism. (n.d.).

Data from Santek Consultants Pvt. Ltd. (n.d.).

Economic Report by Indian Brand Equity Foundation (IBEF) on J\&K. (2019).

Government Report on J\&K Tourism (2014 \& 2015). (n.d.).

Ministry of External Affairs Annual Report 2011-2012. (2011). Retrieved from http://mea .gov.in/Uploads/PublicationDocs/19337_annual-report-2011-2012.pdf

Nengroo, A. H., Bhat, G. M., \& Khaki, A. R. (2016). Economic impact of Tourism in Jammu and Kashmir. Indian Journal of Economics and Development., 4(3).

Paul, D. Y. (2018). Economic profile of Jammu \& Kashmir state: An overview, International Journal of Advanced Educational Research., 3(1), 114-119.

The role of ICT in tourism industry. (n.d.). Retrieved from http://www.aebjournal.org/ articles/0104/010406.Dateaccessed:25/05/2015

Santek Consultants Pvt. Ltd. New Delhi. (n.d.).

Singh, D. S., \& Magray, J. M. (2017). Role And Performance of Tourism in Jammu And Kashmir Economy, International Journal of Scientific Research and Education., 5(8), 68336838.

T, N. K., \& A, D. B. T. (2017). AN ANALYTICAL STUDY ON CONTRIBUTIONS OF TOURISM INDUSTRY IN INDIA, INTERNATIONAL JOURNALOF CURRENT RESEARCH., 9(7), 53706-53710.

Various Research Articles on Tourism from Research Gate. (n.d.).

World tour and travel council. (n.d.). 